\title{
Gene Expression of the Expansin Family in Silk Cotton under Water Stress
}

\author{
Luciana Cardoso Nogueira Londe ${ }^{1}$, Emanuelle Ferreira Melo de Pinho ${ }^{2}$ \\ ${ }^{1}$ Empresa de Pesquisa Agropecuária de Minas Gerais, Unidade Regional Epamig Norte de Minas. \\ Rodovia MGT 122, Km 155, Caixa Postal 12, CEP 39527-000 Nova Porteirinha, MG Brazil. \\ ${ }^{2}$ Faculdades Santo Agostinho. Avenida Osmani Barbosa. JK. \\ 39525000 - Montes Claros, MG - Brazil. \\ ${ }^{1}$ luciana@epamig.br, ${ }^{2}$ emanuellemelo@yahoo.com.br
}

\begin{abstract}
The work aimed was the characterization of gene expression of the expansins family in C. procera plants subjected to water stress. Plants at five months were subjected to drought stress for 30 days. Were collected leaves and roots, which were washed, frozen in liquid $N_{2}$ and stored in a freezer at $-80^{\circ} \mathrm{C}$, until the conclusion of the analysis. Were performed RNA extraction, cDNA obtain and real-time quantitative PCR using specific primers for the expansins gene family CpEXPA1, CpEXPA2, CpEXPA3 and CpEXPA4. Seedlings of $C$. procera resist water stress by up to 30 days, with wilting and yellowing of the upper leaves and leaffall lower. The quantification of RNA ranged from 482,6 $\mathrm{ng} / \mu \mathrm{L}$ until $2553,8 \mathrm{ng} / \mu \mathrm{L}$. The conversion of the RNA into cDNA showed good quality ranging from 48,8 to 176,1 $\mu \mathrm{L}$. The expression of the gene expansins family showed significant differences only when this expression was evaluated in the leaves. The roots showed no significant differences between treatments. The highest levels of expression were found in isoforms CPEXPA3 and CPEXPA4, where we observed an increase in expression of the same due to water stress.
\end{abstract}

Keywords: Calotropis procera, water deficit, molecular characterization, RT-qPCR.

\section{INTRODUCTION}

The species Calotropis procera belongs to the family Asclepidaceae, with 280 genera and 2000 species. It is also known as silk cotton, jealousy, silkpane or janaúba. It is a perennial plant, shrub or subarbórea, being able to reach $3 \mathrm{~m}$ of height, but generally occurring in smaller size, when in soils of low fertility. Silk cotton is often found in the Northeast and Cerrado areas. It is an invading plant of pastures, roadsides, vacant lots and agricultural crops, presenting great capacity of recovery after mowing or cuts. It occurs in regions with high temperature, adapting to the most varied environmental conditions, tolerating poor soils, including highly sandy, acid soils and high aluminum content (Lorenzi, 2000).

This plant occurs naturally in Africa and Asia (Boutraa, 2010), and today has a wide geographical distribution, spreading very easily in arid and semi-arid regions where the dispersion is favored by presenting winged seeds surrounded by a plumage that facilitates its Transport by wind (Souto et al., 2008). According to Melo et al. (2001), cotton has excelled in the adaptation to semi-arid and arid regions, developing satisfactorily in degraded soils and in places with low rainfall rates, remaining green and exuberant throughout the year. In the Janaúba - MG region, for example, during the rainy season, while all vegetation is without vitality, this species presents intact in its morphological and phenotypic conditions, presenting great resistance to drought.

According to Bergamaschi \& Matzenauer (2009), climate is the main factor responsible for the oscillations and frustrations of agricultural crops in Brazil. Current forecasts point to an increase in global warming in the coming decades and there is a consensus that the changing climate that is happening and the stresses generated by these extreme situations will continue to impose ever more difficult conditions for plant cultivation in many parts of the world (White et al., 2004).

In tropical conditions, agricultural productivity may be negatively affected by a series of biotic and abiotic stresses that alter plant growth and development (Silva et al., 2012). In this context, there are mainly prolonged droughts, responsible for the great variability of agricultural production. According 
to Cortez (2004), global warming will account for $20 \%$ of the increase in water scarcity, not only in drought-prone areas but also in tropical and subtropical areas.

The effect of water deficiency depends on the time of occurrence and its severity. Therefore, the characterization of tolerant or drought-sensitive genotypes is a prerequisite for genetic selection and manipulation. The identification of drought tolerance mechanisms in plants is essential in the development of new, more tolerant crops. The differential expression of as yet unidentified genes in tolerant genotypes can be used to study these tolerance mechanisms. A specific physiological response to water deficit represents, in fact, combinations of molecular events that are activated or deactivated by the perception of stress (Bray, 1993). Understanding how events interact with each other will be an important step in developing greater drought tolerance.

In the literature, studies related to the expression of Expansin family genes in C. procera are found (Cheema et al., 2010; Bajwa et al., 2013). Expansins (EXPs) constitute an important family of genes involved in the expansion of plant cells and relaxation of the cell wall. Its optimal activity occurs at acidic $\mathrm{pH}$, since it is in this condition that plant cells grow faster and the wall becomes more flexible (Cosgrove et al, 2002). Expansins hydrolyze the bonds between hemicellulose and cellulose microfibrils and thus induce the irreversible stretching / extension of the cell wall and also its relaxation. They also play an important role in plant development processes such as organogenesis, seed germination and fruit ripening (Li et al., 2003).

It is believed that the expansins interrupt non-covalent bonds, such as hydrogen bonds, at the interface of cellulose and hemicellulose, thus limiting the turgor present in cell expansion. In the present study, it was found that the expression of the expansin-like A (EXLA) and expansin-like B (EXLB) (Kende et al., 2004). A-exps, which represent the largest family, refer to a group of highly conserved proteins that probably controls cell wall extension and developmental processes, including dissociation and separation of cells. B-exps, which make up the second largest family, are secreted by grass pollen and promote intense degradation of the cell wall of the pollen grains. In response In response to stress, some genes have their levels of expression increased, while others repressed (Rodríguez et al., 2005). In this sense, the study of these genes in plants of C. procera submitted or not to water stress would allow the knowledge of the behavior of the genes of the expansin family under conditions of water deficit.

The RT-qPCR technique is one of the most used methods for the quantification of genes due to its dynamicity, sensitivity, specificity, no need for post-amplification processes and high reproducibility (Wong \& Medrano, 2005). This method has been used to monitor gene expression in plants (Gachon et al., 2004), considering its great ability to discriminate related and low expression genes (Czechowski et al., 2004).

The RT-qPCR allows monitoring of the amplification during the exponential phase of the reaction and an accurate determination of the amount of material present (Gachon et al., 2004). There are several methods of detection that can be used in real-time PCR, the most common being the use of SYBR Green. This reagent binds between the DNA double strand and with the excitation of the light emitted by the optical system emits a green fluorescence. Its great advantage is its low cost, ease of use and sensitivity (Novais \& Pires-Alves, 2004).

Fluorescence signals are generated by fluorophores that are specific for double strand DNA (dsDNA) or by fluorescence-tagged primers in specific regions (Klein et al., 2002). The signal is proportional to the amount of PCR product and the equipment detects the accumulation of the amplified product during each reaction cycle. The data are then measured in the exponential phase of the PCR reaction (Meyers et al., 2004).

Understanding of drought tolerance events as well as the development of technologies that help plants withstand prolonged periods of drought are alternatives for the maintenance of Brazilian and world agricultural production. Considering that water deficiency is one of the main determinants of productivity in most crops, this work aimed to characterize the expression of expansin family genes in C. procera under conditions of water stress.

\section{Material AND Methods}

This work was conducted at the Minas Gerais Agricultural Research Company - EPAMIG, located in Nova Porteirinha, MG and at the Health Research Laboratory of the University Hospital Clemente de 
Farias, belonging to the Universidade Estadual de Montes Claros - UNIMONTES, located in Montes Claros, MG.

To obtain the plants used in the experiment, sowing was carried out in plastic bags with a capacity of 3 liters, containing as substrate the mixture of soil and cattle manure (Figure 1A). Five seeds of silk cotton per bag were sown from mature fruits collected in plants located at EPAMIG. 15 days after sowing (Figure 1B), the plants were thinned, leaving only one plant per plastic bag (Figure 1C). The plants were kept in a greenhouse covered with sombrite 50\% interception of solar radiation.

The plants were irrigated daily, maintaining the water level of the substrate close to the field capacity, during five months, when the plants were already well developed and vigorous (Figure 1D). When treatments were established, one group of seedlings continued to be irrigated daily (control), while another group was submitted to the total suspension of watering for up to 30 days.

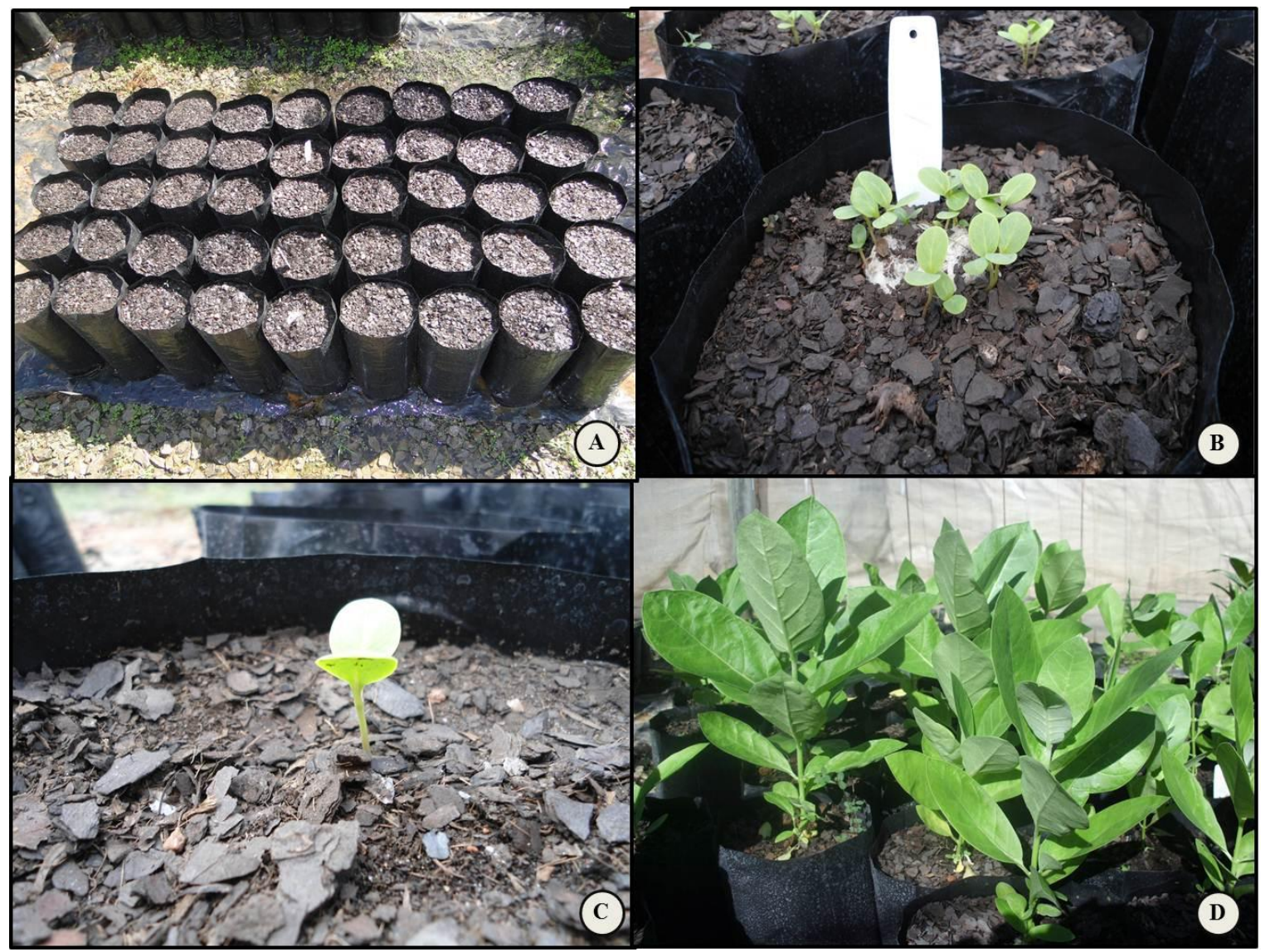

Figure 1. A - Planting silk cotton seeds in plastic bags. B - Silk-cotton seedlings after fifteen days of sowing. $C$ Thinning of silk cotton plants, remaining one plant per plastic bag D - Silk cotton plants at five months after sowing.

Leaf and root samples were collected, washed with distilled water and immediately frozen in liquid $\mathrm{N} 2$, in order to avoid the action of RNases. In the laboratory, the material was stored in a freezer at $80^{\circ} \mathrm{C}$ until the analysis was completed. The experiment was set up in a completely randomized design (DIC), with five replicates per treatment. Each repetition corresponded to a plant.

Total RNA extraction was performed from $100 \mathrm{mg}$ leaf and root samples of plants irrigated continuously and under water stress. Trizol reagent (Life Technologies - Gibco BRL) was used according to the manufacturer's recommendations.

Samples were quantified by spectrophotometry using the NanoDrop 2000 apparatus according to the specifications for the quantification of nucleic acids recommended by the manufacturer. White (internal control and absence of RNA) $\mathrm{H} 2 \mathrm{O}$ treated with $0.1 \%$ DEPC (diethylpyrocarbonate) was used as the blank. Subsequently, the quality of the material was analyzed in $1 \%$ agarose gel, to verify the integrity of the extracted RNA.

After extraction of total RNA from each sample, they were treated with DNAse to avoid contamination with genomic DNA, in the following reaction: $1 \mu \mathrm{L}$ of RNA $(1 \mu \mathrm{g} / \mu \mathrm{L}) ; 1 \mu \mathrm{L}$ of $10 \mathrm{X}$ 
PCR Buffer without $\mathrm{Mg} ; 3 \mu 150 \mathrm{mM} \mathrm{MgCl} 2 ; 0.2 \mu \mathrm{l}$ of DNAse I 250 and $0.1 \%$ DEPC water required to complete the reaction volume to $10 \mu \mathrm{l}$. The mixture was incubated for 15 minutes at room temperature. Then $1 \mu \mathrm{l}$ of $2.5 \mathrm{mM}$ EDTA was added to the mix and it was incubated again at $65^{\circ}$ for 10 minutes, followed by immediate incubation on ice for 1 minute. To the product of this reaction was added $0.1 \mu \mathrm{L}$ of random primer (OligodT). Then the reaction was heated at $70^{\circ} \mathrm{C}$ for 5 minutes to denature secondary RNA structures. After this period the material was cooled to $4^{\circ} \mathrm{C}$ for the hybridization of the oligodT to the RNA without the formation of secondary structures. The product of this reaction was used for retrotranscription.

For each $1 \mu \mathrm{g}$ of DNAse treated RNA, $1 \mu \mathrm{DNTP}, 0.5 \mu \mathrm{l}$ RNAsin (Ribonucleaseinhibitor), $6 \mu \mathrm{L}$ FirstStrand Buffer (transcriptase buffer), $0.5 \mu \mathrm{L}$ retrotranscriptase, $10 \mu \mathrm{L}$ RNA Treated with Oligo DT and DEPC water required to make up the volume to $30 \mu \mathrm{L}$. This reaction was incubated at $37^{\circ} \mathrm{C}$ for one hour and then heated to $65^{\circ} \mathrm{C}$ for 5 minutes. The product of this reaction, cDNA, was stored in a freezer at $-20^{\circ} \mathrm{C}$ and used later in real-time PCR reactions.

Real-time PCR analyzes were performed on the PlusOneplatform (AppliedBiosystems ${ }^{\circledR}$ ), at the Health Research Laboratory, at the State University of Montes Claros. All reactions were subjected to the same analysis conditions using SYBR Green reagent (AppliedBiosystems®, USA).

Specific primers were used for $C$. procera species, using the genes from the Expansinas family CpEXPA1, CpEXPA2, CpEXPA3 and CpEXPA4. These primers were described by Cheema et al. (2010). The 18S RNAr gene was used as endogenous control in each treatment for the normalization of reactions.

Table 1 shows the sequences of the primers and the estimated size of the fragments generated. The cycling parameters for the reactions were $50^{\circ} \mathrm{C}$ for $2 \mathrm{~min}, 95^{\circ} \mathrm{C}$ for $10 \mathrm{~min}$ and then 45 cycles of 95 ${ }^{\circ} \mathrm{C}$ for $2 \mathrm{~min}, 62^{\circ} \mathrm{C}$ for $30 \mathrm{~s}$ and $72^{\circ} \mathrm{C}$ for $30 \mathrm{~s}$. The comparative $\mathrm{CT}$ method was used to compare gene expression levels between the groups using the 2- $\Delta \Delta \mathrm{CT}$ equation (Livak \& Schimittgen, 2001).

Table 1. Sequence of primers used in RT-qPCR and size of generated fragments.

\begin{tabular}{|c|c|c|c|}
\hline Gen & Primer & Primer Sequence & Size $(\mathbf{p b})$ \\
\hline СрЕХРА1 & $\begin{array}{l}\text { CpExp1F BD } \\
\text { CpExp1R BD }\end{array}$ & $\begin{array}{c}\text { 5' TCTTCAATAATGGACTTAGC 3' }{ }^{\prime} \\
\text { GAGGAACATAGGCATAGC 3' }\end{array}$ & 200 \\
\hline СрЕХРА 2 & $\begin{array}{l}\text { CpExp2F BD } \\
\text { CpExp2R BD }\end{array}$ & $\begin{array}{l}\text { 5’ ATGCTTCTGGAACGATGG 3' 5’ } \\
\text { TGGCGGTGACTATAATGC 3' }\end{array}$ & 186 \\
\hline СрЕХРАЗ & $\begin{array}{l}\text { CpExp3F BD } \\
\text { CpExp3R BD } \\
\end{array}$ & $\begin{array}{l}\text { 5' TCTGTCCACCTAATCCTTCC 3' 5' }^{\prime} \\
\text { CCGTTGATTGTAACCTTATTCC 3' }\end{array}$ & 181 \\
\hline СрЕХРА4 & $\begin{array}{l}\text { CpExp4F BD } \\
\text { CpExp4R BD }\end{array}$ & $\begin{array}{c}\text { 5' GCCACTCTTACTTCAACTTG 3' 5' } \\
\text { CTACACTCCGACCATCAC 3' }\end{array}$ & 195 \\
\hline $18 s r R N A$ & $\begin{array}{l}\text { RT18sF } \\
\text { Rt18sR }\end{array}$ & 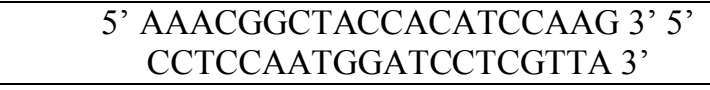 & 153 \\
\hline
\end{tabular}

The experiment was composed of two biological replicates for each gene evaluated and the results observed were submitted to statistical analysis by transferring the data to GraphPadPrism software (version 5.0®, San Diego, USA) and to specific assays with a statistical confidence of $95 \%$ (P $<0.05)$. Data were expressed through mean expression of the evaluated genes. The statistical significance of the differences in mean values between the groups of plants were evaluated by the Student $\mathrm{t}$ test.

\section{RESULTS AND DiSCUSSION}

Silk cotton seedlings at five months of age resisted water stress well for up to 30 days. At that time, the plants already presented with wilting and yellowing of the upper leaves and fall of the lower leaves. These results are corroborated by Boutraa (2010), who imposed different conditions of water stress on silk cotton observed a significant reduction in the number of leaves in this species according to the increase of water stress.

In total, 20 extractions of total RNA from leaves and roots submitted to water stress were performed. The results of quantification and quality of the samples were obtained by spectrophotometry using the Nano Drop 2000 and are arranged in Table 2. 
Table 2. Quantification of total RNA samples obtained by spectrophotometry through Nano Drop 2000 (ng / $\mu L)$.

\begin{tabular}{|l|l|l|l|l|}
\hline \multirow{2}{*}{ Repetition } & Control & Water stress \\
\cline { 2 - 5 } & Leaves & Roots & Leaves & Roots \\
\hline $\mathbf{1}$ & 1557,0 & 1800,5 & 815,0 & 1937,2 \\
\hline $\mathbf{2}$ & 2249,0 & 1919,8 & 996,3 & 2553,8 \\
\hline $\mathbf{3}$ & 1933,9 & 1832,2 & 956,3 & 713,8 \\
\hline $\mathbf{4}$ & 846,8 & 1321,7 & 943,2 & 1767,9 \\
\hline $\mathbf{5}$ & 482,6 & 1026,9 & 1174,1 & 1921,2 \\
\hline
\end{tabular}

In general, extractions of total RNA for all samples showed an excellent yield. The minimum amount extracted was $482.6 \mathrm{ng} / \mu \mathrm{L}$ and the maximum was $2553.8 \mathrm{ng} / \mu \mathrm{L}$, with an overall mean of approximately $1437.46 \mathrm{ng} / \mu \mathrm{L}$.

Figure 2 shows a $1 \%$ agarose gel loaded with the leaf and root samples to check the quality of the extracted samples. The two major bands at the center correspond respectively to the subunits $18 \mathrm{~S}$ and $28 \mathrm{~S}$ of the rRNA, the diffuse lower bands correspond to the mRNA.

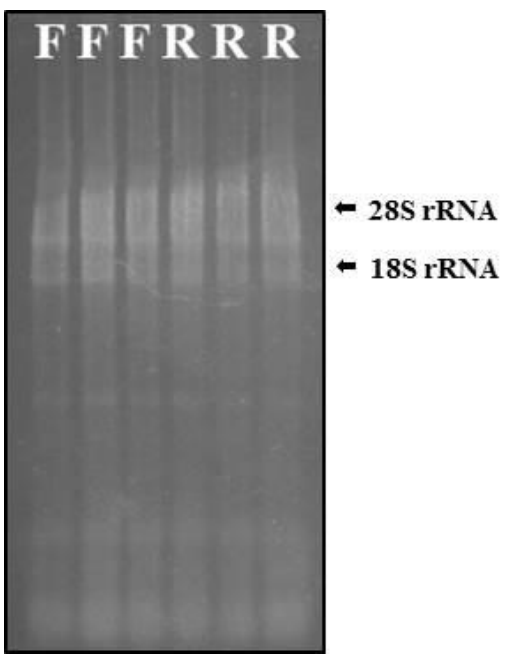

Figure 2. A $1 \%$ agarose gel loaded with total RNA samples from leaves $(F)$ and roots $(R)$ of silk cotton to verify the integrity of extracted RNA samples, represented by bands $28 S$ and $18 S$.

The cDNAs obtained through the total RNA were quantified to verify the quality of the samples by spectrophotometry using the Nano Drop 2000, the results are arranged in Table 3 . The conversion of the RNA in cDNA presented a good quality and with high values, Ranging from 48.8 to $176.1 \mathrm{ng} /$ $\mu \mathrm{L}$.

Table 3. Quantification of the cDNA obtained by spectrophotometry through Nano Drop 2000 ( $\mathrm{ng} / \mu \mathrm{L})$.

\begin{tabular}{|l|l|l|l|l|}
\hline \multirow{2}{*}{ Repetition } & Control & Water stress & \\
\cline { 2 - 5 } & Leaves & Roots & Leaves & Roots \\
\hline $\mathbf{1}$ & 94,2 & 89,2 & 69,7 & 101,6 \\
\hline $\mathbf{2}$ & 58,1 & 62,4 & 51,5 & 76,0 \\
\hline $\mathbf{3}$ & 110,7 & 55,6 & 80,7 & 107,2 \\
\hline $\mathbf{4}$ & 176,1 & 148,7 & 56,7 & 48,8 \\
\hline $\mathbf{5}$ & 59,4 & 59,2 & 79,1 & 89,4 \\
\hline
\end{tabular}

In the real-time PCR analyzes, all primers tested were effective in this process. Measurements on the expression of the expansin family genes in C. procera plants showed significant differences only when the expression of these genes in the leaf was evaluated. When the expression of the CpEXPA1 gene was evaluated in leaves (Figure 3A), a significant drop $(\mathrm{p}=0.021)$ was observed in the expression of this gene under conditions of water stress when compared to the control. For the roots of this same gene (Figure 3B), stress conditions did not affect the activity of this gene, and these two treatments did not differ statistically $(\mathrm{p}=0.645)$. The expression of this gene was higher in the roots when compared to the expression observed in the leaves.

The CpEXPA2 gene in the leaves (Figure 3C) presented similar behavior to the expression of the CpEXPA1 gene, that is, under stress conditions there was a sudden decrease in its expression $(\mathrm{p}=$ 
0.009). For the roots (Figure 3D) no differences were observed between the conditions of plant management ( $\mathrm{p}=0.424)$. For the CpEXPA3 and CpEXPA4 genes in the leaves (Figures 3D and 3F), a response contrary to the other two genes was observed, even though no statistical differences between the treatments were observed $(\mathrm{p}=0.491$ and $\mathrm{p}=0.186)$, expression levels observed for Plants under stress were higher. For the roots (Figures 3D and 3F), in these two genes also no statistical differences between treatments were found $(\mathrm{p}=0.490$ and $\mathrm{p}=0.224)$. The highest expression levels of the expansin family genes were found in the CpEXPA3 and CpEXPA4 isoforms, where an increase in their expression was found due to water stress, as a possible way of maintaining turgor and survival during stress.

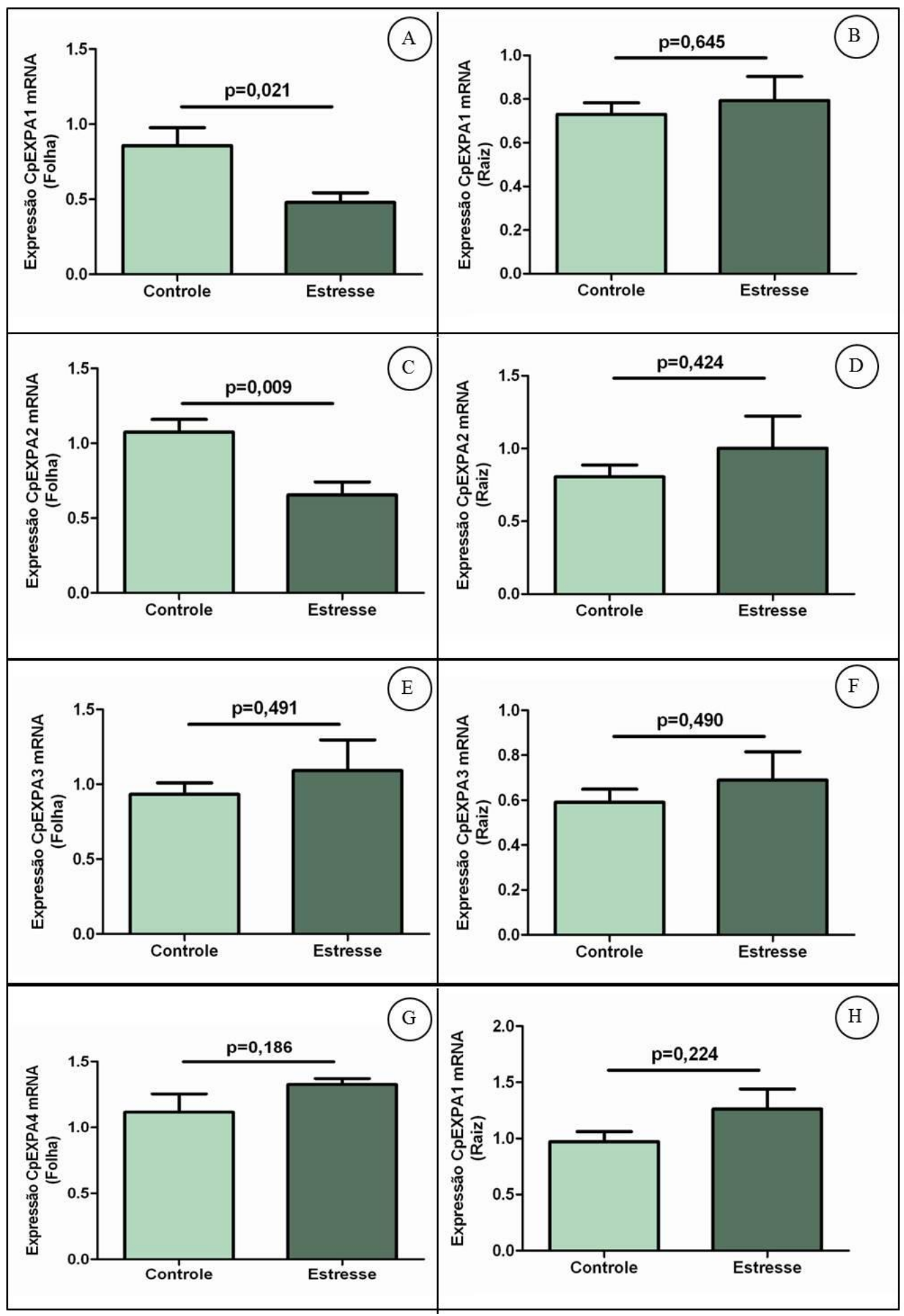

Figure 3. Relative expression of the expansin family genes, estimated by the RT-qPCR technique in plants of $C$. procera submitted or not to water stress. A-CPEXPA1 in leaves. B-CpEXPA1 in roots. C-CpEXPA2 in sheets. $D$ - CpEXPA2 in roots. $E$ - CPEXPA3 in leaves. $F$ - CPEXPA3 in roots. G-CpEXPA4 in leaves. $H$ - CpEXPA4 in roots. 
Cheema et al. (2010) carried out the identification and relative quantification of four expansins in roots, stem, leaves and fibers of $\mathrm{C}$. procera and indicated that, transcripts of CpEXPA1, CpEXPA2, CpEXPA3 and CpEXPA4 are variably transcribed in these tissues. Still according to the same authors, studies of the relative expression of these genes revealed that none of these expansins are fiber-specific, however, transcribed maxima were produced for CpEXPA1 in stems and fibers compared to other tissues. The highest transcript of CpEXPA2 was observed in the leaves, along with CpEXPA4, whereas the highest accumulation of CpEXPA3 transcripts was observed in the stem.

According to the same author, the lowest transcription of all four expansin isoforms was observed in the roots, indicating that the root elongation may be related to other specific expansins except those confined to the growth organs. In the present work, in the evaluation of the relative expression of the expansins in the roots, besides not being observed significant differences between the activity of the expansins in the different treatments, the expression of the same in the roots was also smaller when compared the expression in the leaves.

The expansins are proteins that promote the relaxation and extension of the cell wall in plants, being codified by a gene multifamily and classified in: $\alpha$-expansins, $\beta$-expansins, expansin-like A (EXLA) and expansin-like B (EXLB). These proteins act on cell stretching, fruit softness, abscission, germination and pollination. The $\alpha$-expansins represent the largest family and are directly related to the control of cell wall extension in developmental processes (Budzinski et al., 2007). In this sense, under conditions of water stress, the expression of these genes is significantly affected in C. procera, mainly in the leaves. The change in the expression profile of these genes indicates their participation in water stress protection mechanisms as a possible form of survival during this period. In this situation of water deficit intense retraction of the cell wall, resulting in pronounced leaf wilt and foliar abscission. The timely identification of genes involved in the responses to water deficit will enable future identification and understanding of metabolic pathways involved in the physiological responses to drought.

\section{Conclusions}

1. C. procera seedlings at five months of age resist water stress for up to 30 days.

2. Extractions of total RNA showed a high yield, ranging from $482.6 \mathrm{ng} / \mu \mathrm{L}$ to $2553.8 \mathrm{ng} / \mu \mathrm{L}$, with a general average around $1437.46 \mathrm{ng} / \mu \mathrm{L}$.

3. The conversion of RNA into cDNA showed good quality and high values ranging from 48.8 to $176.1 \mathrm{ng} / \mu \mathrm{L}$.

4. The expression of the expansins presented significant differences only in the leaf. The roots did not present significant differences between the treatments.

5. The highest expression levels of the expansin family genes were found in the CpEXPA3 and CpEXPA4 isoforms under water stress.

\section{ACKNOWLEDGMENTS}

The authors thank the Fundação de Amparo à Pesquisa de Minas Gerais (FAPEMIG - Brazil), to Universidade Estadual de Montes Claros and to the Laboratory of Health Research of the University Hospital Clemente Faria for the opportunity of conducting the PCR analyzes in real time.

\section{REFERENCES}

[1] BAJWA, K.S.; SHAHID, A.A.; RAO, A.Q.; KIANI, M.S.; ASHRAF, M.A.; DAHAB, A.A.; BAKHSH, A.; LATIF, A.; KHAN, M.A.U.; PUSPITO, A.N.; AFTAB, A., BASHIR, A.; HUSNAIN, T. Expression of Calotropis procera expansin gene CpEXPA3 enhances cotton fibre strength. Australian Journal of Plant Science, v.7, p.206-212, 2013.

[2] Bergamaschi, H.; MATZENAUER, R. Milho. In: MONTEIRO, J. E. B. A. (Ed.) Agrometeorologia dos cultivos: o fator meteorológico na produção agrícola. Brasília, DF: INMET, 2009. p. 238-260.

[3] BOUTRAA, T. Effects of Water Stress on Root Growth, Water Use Efficiency, Leaf Area and Chlorophyll Content in the Desert Shrub Calotropis procera. Journal of International Environmental Application \& Science, v.5, p.124-132, 2010.

[4] BRAY, E. A. Molecular responses to water deficit. Plant Physiology, v.103, p.1035-1040, 1993. 
[5] BUDZINSKI, I. G. F.; PEREIRA, L. F. P.; VIEIRA, L. G. E. Caracterização in silico de genes de expansina presentes em cafeeiro (Coffeaarabica L.). In: SIMPÓSIO DE PESQUISA DOS CAFÉS DO BRASIL, 5., 2007, Águas de Lindóia. Anais. Brasília, DF: Embrapa Café, 2007.

[6] CHEEMA, H.M.N.; BASHIR, A.; KHATOON, A.; IQBAL, N.; ZAFAR, Y.; MALIK, K.A. Molecular characterization and transcriptome profiling of expansin genes isolated from Calotropis procera fibers. Electronic Journal of Biotechnology, v.13, p.10-11, 2010.

[7] CORTEZ, H. Consciência e meio ambiente: aquecimento global e água. 2004. 120p.

[8] COSGROVE, D.J.; LI, L.C.; CHO, H.T.; HOFFMANN-BENNING, S.; MOORE, R.C. and BLECKER, D. The growing world of expansins. Plant \& Cell Physiology, v.43, p.1436-1444, 2002.

[9] CZECHOWSKI, T.; BARI, R.P.; STITT, M.; SCHEIBLE, W.R.; UDVARDI, M.K. Real-time RT-PCR profiling of over 1400 Arabidopsis transcription factors: Unprecedented sensitivity reveals novel rootand shoot-specific genes. Plant Journal, v.38, p.366-379, 2004.

[10] GACHON, C.; MINGAM, A.; CHARRIER, B. Real-time PCR: what relevance to plant studies. Journal of Experimental Botany, v.55, p.1445-1454, 2004.

[11] KENDE, H.; BRADFORD, K.; BRUMMELL, D.; CHO, H.T.; COSGROVE, D.J.; FLEMING, A.; GEHRING, C.; LEE, Y.; MCQUEEN-MASON, S.; ROSE, J.; VOESENEK, L. Nomenclature for members of the expansin superfamily of genes and proteins. Plant Molecular Biology, v.55, p.311-314, 2004.

[12] KLEIN, C. A.; SEIDL, S.; PETAT-DUTTER, K.; OFFNER, S.; GEIGL, J. B.; SCHMIDTKITTLER, O.; ENDLER, N.; PASSLICK, B.; HUBER, R. M.; SCHLIMOK, G.; BAEUERLE, P. A.; RIETHMULLER, G. Combined transcriptome and genome analysis of single micrometastatic cells. Nature Biotechnology, v. 20, p. 387-392, 2002.

[13] LI, Y.; JONES, L.; McQUEEN-MASON, S.J. Expansins and plant cell growth.Current Opinion Plant Biology, v.6, p.603-610, 2003.

[14] LIVAK, K.J.; SCHMITTGEN, T.D. Analysis of relative gene expression data using real-time quantitative PCR and the 2(-Delta DeltaC (T)) Method. Methods, v.25, p.402-408, 2001.

[15] LORENZI, H. Árvores brasileiras: manual de identificação e cultivo de plantas arbóreas nativas do Brasil. 4. ed. Nova Odessa: Plantarum, 2000, 368 p.

[16] MELO, M.M.; VAZ, F.A.; GONÇALVES, L.C.; SATURNINO, H.M. Estudo fitoquímico da Calotropis procera Ait., sua utilização na alimentação de caprinos: efeitos clínicos e bioquímicos séricos. Revista Brasileira de Saúde e Produção Animal, v.2, p.15-20, 2001.

[17] MEYERS, B. C.; GALBRAiTH, D. W.; NELSON, T.; AGRAWAL, V. Methods for transcriptional profiling in plants be fruitful and replicate. Plant Physiology, v.135, p.637-652, 2004.

[18] NOVAIS, C.M. \& PIRES-ALVES, M. PCR em tempo real: uma inovação tecnológica da reação em cadeia da polimerase. Biotecnologia, Ciência \& Sociedade, v.33, p. 10-13, 2004.

[19] RODRÍGUEZ, M.; CANALES, E.; BORRÁS-HIDALGO, O. Molecular aspects of abiotic stress in plants. Biotecnologia Aplicada, v.22, p.1-10, 2005.

[20] SILVA, H.A.P.; GALISA, P.S.; OLIVEIRA, R.S.S.; VIDAL, M.S.; SIMÕES-ARAÚJO, J.L. Expressão gênica induzida por estresses abióticos em nódulos de feijão-caupi. Pesquisa Agropecuária Brasileira, v.47, p.797-807, 2012.

[21] SOUTO, P.C.; SALES, S.C.V.; SOUTO, J.S.; SANTOS, R.V.; SOUSA, A.A. Biometria de frutos e número de sementes de Calotropis procera (Ait.) $\mathrm{R} . \mathrm{Br}$ no semi-árido da Paraíba. Revista Verde, v.3, p.108-113, 2008.

[22] WHITE, J. W.; MCMASTER, G. S.; EDMEADES, G. O. Genomics and crop response to global change: what have we learned? Field Crops Research, v.90, p.65-169, 2004.

[23] WONG, M.L. \& MEDRANO, J.F. Real-time for mRNA quantitation. BioTechniques, v.39, n.1, 2005. 